\author{
Military Technical College \\ Kobry El-Kobbah, \\ Cairo, Egypt
}

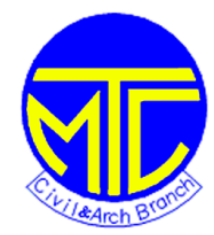

\section{0th International Conference on Civil and Architecture Engineering}

ICCAE-10-2014

\title{
The Best Criteria for the Selection of Consultant Offices Construction Industry in Libya
}

\author{
Y. Alamiri ${ }^{*}$, S. Mahfouz ${ }^{\ddagger}$, N. Amer ${ }^{\dagger}$
}

\begin{abstract}
A questionnaire has been designed and presented to determine the most important criteria affecting the choice of the best consulting offices in construction projects in the public sector in Libya. The questionnaire consists of Ninety-nine sub-criterion covering on two main fields. The first field: human resources contain six main criteria and thirty-four sub-criteria. The second field: physical possibilities contain sixteen main criteria and sixty-five sub-criteria. The questionnaire is spreaded over expert engineers, to rate the criteria on likert scale, ( 1 to 5$)$. The validity and reliability of the questionnaire have been tested to ensure that the collected data is meaningful. In order to ensure the veracity of the internal consistency of the questionnaire, the questionnaire has been distributed over the decisionmaker experts to calculate the correlation coefficient Pearson. In the reliability analysis, Cronbach's Alpha coefficient and arithmetic average of results have been determined utilizing the Statistical Package for Social Sciences (SPSS).

Finally, the study shows that there are seven main criteria that mainly control the selection of the consulting office. These criteria are human capabilities, office experience, previous performance level, quality control, office equipment, administrative system, training and development.
\end{abstract}

\section{Keywords}

Consulting offices selection criteria, validity and reliability, correlation coefficient Pearson, Cranach's Alpha coefficient, Libya construction industry

* Libyan Army, Libya. Email: murm2007@yahoo.com

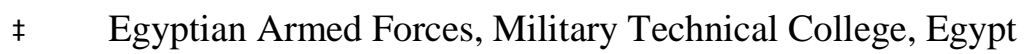

$+\quad$ Egyptian Armed Forces, Military Technical College, Egypt 


\section{Nomenclature}

$\begin{array}{cl}\text { A/E } & \text { Architect / Engineer } \\ \text { CPC } & \text { Consultant Pre-selection Criteria } \\ \text { CPE } & \text { Consultant's Performance Evaluation } \\ \text { DSS } & \text { Decision Support System } \\ \text { EMR } & \text { Experience Modification Rating } \\ \text { HVAC } & \text { Heating Ventilation Air Conditioning } \\ \text { MIS } & \text { Management Information Systems } \\ \text { OSHA } & \text { Occupational Safety and Housing Administration } \\ \text { SPSS } & \text { Statistical Package Social Sciences } \\ \text { r } & \text { Correlation coefficient }\end{array}$

\section{Introduction}

The selection of the consulting office is a vital issue for the achieve project's properly. Few researches were carrying out in this research area. For instance, Kasma [1] studied the selection of consulting engineering firms for professional services by clients in a number of ways. Too many times, the client makes the selection on price rather than qualifications. The recommended selection procedure for selecting a consulting engineer involves: (1) Soliciting qualifications of firms (2) conducting an explanatory meeting (3) receiving consultant proposals (4) selecting firms to interview (5) conducting interviews (6) negotiating a contract with the selected firm. Yean [2] certain attributes of an architect or engineer (A/E) that may be used to predict his performance. These attributes may be categorized as "hard" or "soft" attributes. Hard attributes include an AE's cognitive ability, job knowledge, task proficiency, and job experience. Soft attributes include an AE's conscientiousness, initiative, social skills, controllability, and commitment. The purpose of this study is to identify those attributes that affect an AE's .The results of the study reveal that an AE's performance can be predicted using three attributes: AE's problem solving ability and project approach, AE's speed in producing design drawings, and the AE's level of enthusiasm in tackling a difficult assignment. Thomas [3] aimed to devise a more objective framework for evaluating consultants' general capabilities during the pre-selection process. The paper begins by identifying the commonly used criteria for pre-selecting engineering consultants. In order to examine the importance of consultant pre-selection criteria (CPC), a questionnaire survey was conducted with clients who were responsible for pre-selecting their consultants; and consultants being pre-selected by the clients. The findings reveal that the perception of the client and consultant groups on the importance of (CPC) was very consistent. Finally, a multi-criteria model for evaluating consultants' general capabilities during the pre-selection is proposed. Based on each candidate score, clients can determine which engineering consultants should be invited to bid for a consultancy assignment.

Lai and Thomas [4] conducted a survey to unveil the standards for various performance levels which correspond to a list of indicators used for gauging engineering consultants' performance at the design stage. A modified horizontal approach is employed to analyses the data, and the results indicate that engineering consultants should fulfill greater than $90 \%$ in most of the aspects relevant to the design stage to qualify for an 'excellent' performance rating. By referring to the expected performance standards, clients can identify which 
quantitative indicators at the design stage should deserve much greater attention to minimize the chance of commissioning an incapable engineering consultant. Thomas and Chow [5] improved the transparency and rigorousness of Consultant's Performance Evaluation (CPE) through the establishment of an evaluating framework for gauging the performance of engineering consultants. In this paper, a comprehensive set of evaluation criteria is identified, and the significance of these criteria is discussed through an empirical survey. Then, a multicriteria model for evaluating the performance of engineering consultants is presented. The results indicate that once an acceptable (CPE) framework is devised, the performance scores can be utilized for various purposes, including monitor and control, incentive and sanction, reselection, technical assessment, and bid evaluation. Al-Khunaizi [6] studied the best professional services in the $\mathrm{A} / \mathrm{E}$ selection, the quality of the project's specific criteria. These criteria are the financial, technical, managerial capability and competence of each $\mathrm{A} / \mathrm{E}$ to perform the proposed work. The principles of validity and reliability are fundamental cornerstones of the scientific method.

Many researchers have identified the main criteria for contractor's selection for the public sector of different countries. For instance, Hatush and Skitmore [7] identified the criteria for prequalification and bid evaluation. The findings indicate that the most common criteria considered by procurers during the prequalification and bid process are those pertaining to financial soundness, technical ability, management capability, and the health and safety performance of contractors. The Department of Treasury and Finance [8] introduced guidelines for tender evaluation using weighted criteria for building works and services. Rather than automatically accepting the lowest price, the tender assessment process applies weighting for skills, quality, experience and previous performance in a manner to ensure value for money. Mahdi et al. [9] introduced an approach to structuring a Decision Support System (DSS) to select the optimum contractor. The decision criteria include project time duration, past experience record, the use of discounted cash flow technique, quality of performance and project safety.

Reliability and validity is a major issue when it comes to research, indeed failure to assure the validity and/or reliability of the findings may cause the research to be questioned even worse rejected as invalid. Reliability refers to consistency and/or repeatability of the measurement; in other words, consistency can relate here to the questionnaires being clear and well define in order to not confuse the respondents and repeatability here means that if searchers have findings from a group they should be able to repeat the survey and get exactly the same results. Validity encompasses the entire experimental concept and establishes whether the results obtained meet all of the requirements of the scientific research method, their results are statistically analyzed and the test modified to improve the rational validity [10].

This paper outlines the procedure followed to design questionnaire, and analyze its result. The procedure is divided into four steps: identifying the main criteria and sub-criteria that affect selection and prequalification of consulting offices, designing the study questionnaire, collecting data, and finally analyzing results of the respondents that will be used for further study. 


\section{Questionnaire design}

In order to identify the most effective criteria that affect the selection of the consulting offices, the following procedures are followed:

(1) From the literature review, the most repeated criteria were chosen.

(2) Semi-structured interviews were conducted with construction experts; see Appendix (A) to select the most important criteria. In these interviews, criteria were listed, then mixed, combined, and finally selected to suit the construction industry in Libya. The experts represent all parties of the construction industry in Libya. Accordingly, the sample consists of the decision-makers (owner, consultant, and contractor). Each group has two divisions: public and private. The public owners include ministries, general authorities, administrations...etc. Private owners include contracting companies.

(3) Based on the literature review and the semi-structured interviews, the final list for the criteria that affects the selection of the consulting offices was determined. All criteria represented in Appendix (B).

The final form of the questionnaire consists of (99) sub-criterions that core two main fields.

- Human resources contains (6) main criteria and (34) sub-criteria.

- Physical possibilities contain (16) main criteria (65) sub-criteria.

\section{The internal consistency of the questionnaire}

In statistics and research, internal consistency is typically a measure based on the correlations between different items on the same test (or the same subscale on a larger test). It measures whether several items that propose to measure the same general construct produce similar scores. Internal consistency can be measured by calculating the correlation coefficient between the questionnaire data. To ensure the veracity of the internal consistency of the questionnaire, questionnaire is spreaded over (35) of experienced engineers, given in Appendix (A), in order to calculate the correlation coefficient between all criteria. This step reflects the meaning of the collected data. Correlation coefficient is a statistical measure of the strength of a monotonic relationship between paired data. In a sample, it is denoted by (r) and is by design constrained as follows: $\underline{K} \mathrm{r} \leq+1$ and its interpretation is the closer ( $\mathrm{r}$ ) is to $(+1)$ the stronger the monotonic relationship. For interpreting the correlation coefficient, the rang is assumed as given in Table (1).

Table (1) Interpretation of the correlation coefficient (r) [10]

\begin{tabular}{|c|c|c|}
\hline No. & The value of (r) & Type of relationship \\
\hline & $0.00-0.19$ & very weak \\
\hline 2. & $0.20-0.39$ & weak \\
\hline 3. & $0.40-0.59$ & moderate \\
\hline 4. & $0.60-0.79$ & strong \\
\hline 5. & $0.80-1.0$ & very weak \\
\hline
\end{tabular}

In the current study, the Statistical Package for Social Sciences (SPSS) [11] was used to calculate the correlation coefficients based on Pearson product moment correlation. The results are given in Tables (2), (3). Moreover, arithmetic means are calculated to identify the importance of each criterion of criteria in two fields: i.e. (human resources and physical possibilities). 
Table (2) Correlation coefficient and arithmetic mean for human resources criteria

\begin{tabular}{|c|c|c|c|c|}
\hline No. & Human resources & (r) & Type of relationship & Arithmetic mean \\
\hline \multicolumn{5}{|c|}{ Capacity to accomplish the work } \\
\hline 1 & Availability to qualified personnel & 0.802 & very strong & 2.963 \\
\hline 2 & Professional qualification/experience & 0.712 & strong & 2.963 \\
\hline 3 & Present workload & 0.746 & strong & 2.962 \\
\hline \multicolumn{5}{|c|}{ Human capabilities } \\
\hline 4 & Number of (Engineers) & 0.708 & strong & 2.988 \\
\hline 5 & Experience of (Engineers) & 0.880 & very strong & 2.993 \\
\hline 6 & Training of (Engineers) & 0.789 & strong & 2.986 \\
\hline 7 & Qualification of (Engineers) & 0.842 & very strong & 2.989 \\
\hline 8 & Registry in professional organizations & 0.538 & moderate & 2.986 \\
\hline 9 & Provides disciplines (Engineers) & 0.839 & very strong & 2.986 \\
\hline 10 & Number of. (Technicians ) & 0.625 & strong & 2.989 \\
\hline 11 & Experience of (Technicians) & 0.837 & very strong & 2.986 \\
\hline 12 & Training of (Technicians) & 0.811 & very strong & 2.986 \\
\hline 13 & Qualification of (Technicians) & 0.774 & strong & 2.986 \\
\hline 14 & Registry in professional organizations & 0.535 & moderate & 2.985 \\
\hline 15 & Provides disciplines (Technicians) & 0.810 & very strong & 2.986 \\
\hline \multicolumn{5}{|c|}{ Administrative system } \\
\hline 16 & Procedures manual & 0.745 & strong & 2.975 \\
\hline 17 & Detailed scheduling for every project & 0.607 & strong & 2.973 \\
\hline 18 & Costs management program & 0.555 & moderate & 2.971 \\
\hline 19 & Risk management program & 0.630 & strong & 2.963 \\
\hline \multicolumn{5}{|c|}{ Technical ability and skills } \\
\hline 20 & CV`s to be provided & 0.617 & strong & 2.960 \\
\hline 21 & Personnel & 0.710 & strong & 2.959 \\
\hline 22 & Technical expertise of project team & 0.733 & strong & 2.956 \\
\hline 23 & Plant and equipment & 0.806 & very strong & 2.942 \\
\hline \multicolumn{5}{|c|}{ Office experience } \\
\hline 24 & Years of experience & 0.838 & very strong & 2.984 \\
\hline 25 & $\begin{array}{l}\text { Number previous projects in the same field and } \\
\text { the task }\end{array}$ & 0.812 & very strong & 2.982 \\
\hline 26 & $\begin{array}{l}\text { The average value of previous projects in the } \\
\text { same field and the task } 1 .\end{array}$ & 0.817 & very strong & 2.977 \\
\hline 27 & Number previous projects in the fields and tasks & 0.812 & very strong & 2.981 \\
\hline 28 & $\begin{array}{l}\text { The average value of previous projects in the } \\
\text { fields and other tasks }\end{array}$ & 0.640 & strong & 2.981 \\
\hline 29 & The number of previous owners & 0.834 & very strong & 2.979 \\
\hline 30 & Percentage of owners of previous projects & 0.736 & strong & 2.978 \\
\hline 31 & Working with different contract types & 0.586 & moderate & 2.978 \\
\hline \multicolumn{5}{|c|}{ Training and development } \\
\hline 32 & Staff training & 0.651 & strong & 2.977 \\
\hline 33 & Participate in scientific conferences & 0.844 & very strong & 2.974 \\
\hline 34 & Presence integrated library & 0.803 & very strong & 2.973 \\
\hline
\end{tabular}


Table (3) Correlation coefficient and arithmetic mean for physical possibilities criteria

\begin{tabular}{|c|c|c|c|c|}
\hline No. & Physical possibilities & $(\mathrm{r})$ & Type of relationship & Arithmetic mean \\
\hline \multicolumn{5}{|c|}{ Firm's background } \\
\hline 35 & Reputation & 0.476 & moderate & 3.00 \\
\hline 36 & Technical competence /qualification & 0.764 & strong & 2.977 \\
\hline 37 & Experience with similar project & 0.671 & strong & 2.975 \\
\hline \multicolumn{5}{|c|}{ Project approach } \\
\hline 38 & Approaches to time schedule & 0.473 & moderate & 2.982 \\
\hline 39 & Approaches to quality & 0.542 & moderate & 2.978 \\
\hline 40 & Design approach / methodology & 0.525 & moderate & 2.975 \\
\hline \multicolumn{5}{|c|}{ Financial capability } \\
\hline 41 & Financial statement & 0.535 & moderate & 2.975 \\
\hline 42 & Financial references & 0.422 & moderate & 2.973 \\
\hline \multicolumn{5}{|c|}{ Cost } \\
\hline 43 & Tender price & 0.671 & strong & 2.974 \\
\hline 44 & Transportation cost & 0.783 & strong & 2.971 \\
\hline 45 & Consultancy cost & 0.726 & strong & 2.968 \\
\hline \multicolumn{5}{|c|}{ Communication ability } \\
\hline 46 & Awareness of responsibility & 0.282 & weak & 2.984 \\
\hline 47 & Ability to persuade & 0.388 & weak & 2.963 \\
\hline \multicolumn{5}{|c|}{ Financial soundness } \\
\hline 48 & Financial stability & 0.585 & moderate & 2.967 \\
\hline 49 & Credit rating & 0.355 & weak & 2.960 \\
\hline 50 & Banking arrangements and bonding & 0.303 & weak & 2.955 \\
\hline 51 & Financial status & 0.333 & weak & 2.951 \\
\hline 52 & Liquidity ratio & 0.374 & weak & 2.944 \\
\hline \multicolumn{5}{|c|}{ Reputation } \\
\hline 53 & Past failures & 0.542 & moderate & 2.967 \\
\hline 54 & Past owner / consultant relationship & 0.439 & moderate & 2.967 \\
\hline 55 & Length of time in business & 0.261 & weak & 2.940 \\
\hline 56 & Other relationships & 0.356 & weak & 2.938 \\
\hline \multicolumn{5}{|c|}{ Management capability } \\
\hline 57 & Project management organization & 0.420 & moderate & 2.945 \\
\hline 58 & Experience of technical personnel & 0.806 & very strong & 2.967 \\
\hline 59 & Management knowledge & 0.689 & strong & 2.966 \\
\hline \multicolumn{5}{|c|}{ Health and safety } \\
\hline 60 & Safety & 0.423 & moderate & 2.944 \\
\hline 61 & Experience modification rating (EMR) & 0.555 & moderate & 2.937 \\
\hline 62 & Health and safety on previous projects & 0.605 & strong & 2.966 \\
\hline 63 & $\begin{array}{l}\text { Details of occupational safety and housing } \\
\text { administration (OSHA) }\end{array}$ & 0.396 & weak & 2.937 \\
\hline 64 & Management safety accountability & 0.775 & strong & 2.964 \\
\hline \multicolumn{5}{|c|}{ Relevant experience } \\
\hline 65 & relevance to the tendered project & 0.688 & strong & 2.963 \\
\hline 66 & Role of the tendered & 0.515 & moderate & 2.921 \\
\hline 67 & Project cost & 0.774 & strong & 2.959 \\
\hline 68 & Duration of the project & 0.515 & moderate & 2.921 \\
\hline
\end{tabular}


Table (3) Continue-correlation coefficient and arithmetic mean for physical possibilities criteria

\begin{tabular}{|c|c|c|c|c|}
\hline No. & Physical possibilities & (r) & Type of relationship & Arithmetic mean \\
\hline \multicolumn{5}{|c|}{ Management skills and systems } \\
\hline 69 & Quality system & 0.807 & very strong & 2.958 \\
\hline 70 & Project management tools & 0.792 & strong & 2.952 \\
\hline 71 & Program software & 0.658 & strong & 2.948 \\
\hline 72 & Environmental management system & 0.718 & strong & 2.948 \\
\hline \multicolumn{5}{|c|}{ Methodology } \\
\hline 73 & program of works & 0.617 & strong & 2.941 \\
\hline 74 & Key performance indicators & 0.710 & strong & 2.907 \\
\hline 75 & Division of work into subcontracts & 0.396 & weak & 2.890 \\
\hline 76 & Innovate procedure & 0.597 & moderate & 2.912 \\
\hline 77 & Reporting and recording systems & 0.687 & strong & 2.840 \\
\hline 78 & Quality plan & 0.725 & strong & 2.840 \\
\hline \multicolumn{5}{|c|}{ Price } \\
\hline 79 & Fixed capital cost & 0.779 & strong & 2.890 \\
\hline 80 & $\begin{array}{l}\text { Variable tender costs during the contract } \\
\text { period }\end{array}$ & 0.515 & moderate & 2.890 \\
\hline 81 & $\begin{array}{l}\text { Special adjustments during the contract } \\
\text { period }\end{array}$ & 0.463 & moderate & 2.810 \\
\hline 82 & Maintenance costs & 0.563 & moderate & 2.775 \\
\hline 83 & Operating costs & 0.439 & moderate & 2.773 \\
\hline \multicolumn{5}{|c|}{ Quality control } \\
\hline 84 & Assurance program and quality control & 0.570 & moderate & 2.981 \\
\hline 85 & Obtain certificates quality & 0.704 & strong & 2.981 \\
\hline \multicolumn{5}{|c|}{ Previous performance level } \\
\hline 86 & $\begin{array}{l}\text { Quality standards, target performance } \\
\text { levels }\end{array}$ & 0.546 & moderate & 2.840 \\
\hline 87 & Time control & 0.718 & strong & 2.912 \\
\hline 88 & $\begin{array}{l}\text { Completion date and extensions of time } \\
\text { granted }\end{array}$ & 0.447 & moderate & 2.912 \\
\hline 89 & Failure to completed contract & 0.436 & moderate & 2.907 \\
\hline 90 & Delay & 0.409 & moderate & 2.892 \\
\hline 91 & Cost overruns & 0.382 & weak & 2.890 \\
\hline 92 & $\begin{array}{l}\text { Assess the performance for the previous } \\
\text { projects in the same field and the task }\end{array}$ & 0.708 & strong & 3.00 \\
\hline 93 & $\begin{array}{l}\text { Assess Performance of previous projects in } \\
\text { the other fields and other tasks }\end{array}$ & 0.788 & strong & 2.996 \\
\hline 94 & $\begin{array}{l}\text { Use of self-assessment methodology for } \\
\text { performance }\end{array}$ & 0.695 & strong & 2.989 \\
\hline 95 & Relationship with insurance companies & 0.759 & strong & 2.890 \\
\hline \multicolumn{5}{|c|}{ Office equipment } \\
\hline 96 & Office area & 0.623 & strong & 2.981 \\
\hline 97 & Number consultant office the branches & 0.681 & strong & 2.979 \\
\hline 98 & The use of new technologies & 0.673 & strong & 2.979 \\
\hline 99 & Condition and procedures of equipment & 0.237 & weak & 2.810 \\
\hline
\end{tabular}


The results confirm that the questionnaire has a high degree of internal consistency. Table (2) shows that the study sample answers in human resources when choosing consulting office is very high, reaching the highest value of the arithmetic average (2.993). For the human capabilities criterion / experience engineer and architect. The lowest value of the arithmetic average (2.942) is obtained, for the technical ability and skills criterion / plant and equipment. From the results given in table (3), it is shown that the study sample answers in Physical possibilities when choosing consulting office is very high. It can be seen that the highest value of the arithmetic average is (3.00) for the level of previous performance / assess the performance during the previous projects. The lowest value of the arithmetic average is (2.773) for the price criterion / operating costs. Seven criteria have been identified as a result of their highest value of the arithmetic average, and therefore, considered the most important criteria for the selection of consulting offices in contracts for construction projects in Libya. Figure (1) summarizes the basic criteria for the selection of consulting offices in construction projects in Libya. The validity of the questionnaire has been carried between each of the two fields as given in the table (4). It can be shown that a correlation between each area of the questionnaire with a total score of the questionnaire. This confirms that the questionnaire has a high degree of internal consistency.

Table (4) Correlation coefficient to every fields of the questionnaire

\begin{tabular}{|c|c|c|}
\hline The field & The value of (r) & Type of relationship \\
\hline Human resources & 0.897 & very strong \\
\hline Physical possibilities & 0.844 & very strong \\
\hline
\end{tabular}

\section{Reliability analysis of the questionnaire}

The idea behind reliability [10] is that any significant results must be more than a one-off finding and be inherently repeatable. This will reinforce the findings and ensure that the wider scientific community will accept the hypothesis. Without this replication of statistically significant results, the experiment and research have not fulfilled all of the requirements of testability. This prerequisite is essential to a hypothesis establishing itself as an accepted scientific truth. The SPSS is used to calculate Cronbach's Alpha Coefficient. Table (5) displays the results obtained. Overall the Cronbach's Alpha Coefficient for the questionnaire results is (0.985), which is very high and indicates a strong internal consistency.

Table (5) Statistical results for reliability analysis (Cronbach's Alpha)

\begin{tabular}{|c|c|c|}
\hline The field & No. of items & Cronbach's Alpha \\
\hline Human resources & 34 & 0.974 \\
\hline Physical possibilities & 65 & 0.973 \\
\hline Total of items questionnaire & 99 & 0.985 \\
\hline
\end{tabular}

\section{Conclusion}

The current study shows that there are seven main criteria that mainly control the selection of the consulting office in Libya. These criteria are human capabilities, office experience, previous performance level, quality control, office equipment, administrative system, training 
and development. These seven main criteria consists of (31) sub-criterion for the design stage, and (31) sub-criterion for the supervision stage as shown in Figure 1

\section{References}

[1] Kasma, D.”Consultant Selection” J. Manage. Eng., 1987

[2] Ling, Y. "Model for Predicting Performance of Architects and Engineers" Journal of Construction Engineering and Management, 2002

[3] S. Thomas Ng, Lai-Kit Chow, "Evaluating engineering consultants' general capabilities during the pre-selection process a Hong Kong study" Engineering, Construction and Architectural Management, 2004

[4] Chow, L. and Ng, S. "Delineating the performance standards of engineering consultants at design stage" Construction Management and Economics, 2010

[5] Thomas Ng, S. and Chow, L.”Framework for Evaluating the Performance of Engineering Consultants”, 2004

[6] M.A.M. Al-Khunaizi, a Conceptual Model for Consultant Selection in Saudi Arabia, construction contracting, 2004

[7] Hatush, Z. and Skitmore, M. , Criteria for contractor selection, Construction Management and Economics, 1997

[8] Department of Treasury and Finance, Australia, Tender Evaluation Using Weighted Criteria for Building Works and Services, Tasmania, 1999

[9] Mahdi, I., Fereig, S. and Riley, M., Knowledge-Based Expert System for Selecting the Optimum Contractor, 1999

[10] William. M.K. T., www.socialresearchmethods.net, Reliability and Validity, 2006

[11] Altman D.G, Practical Statistics for Medical Research, Chapman and Hall, 1991 


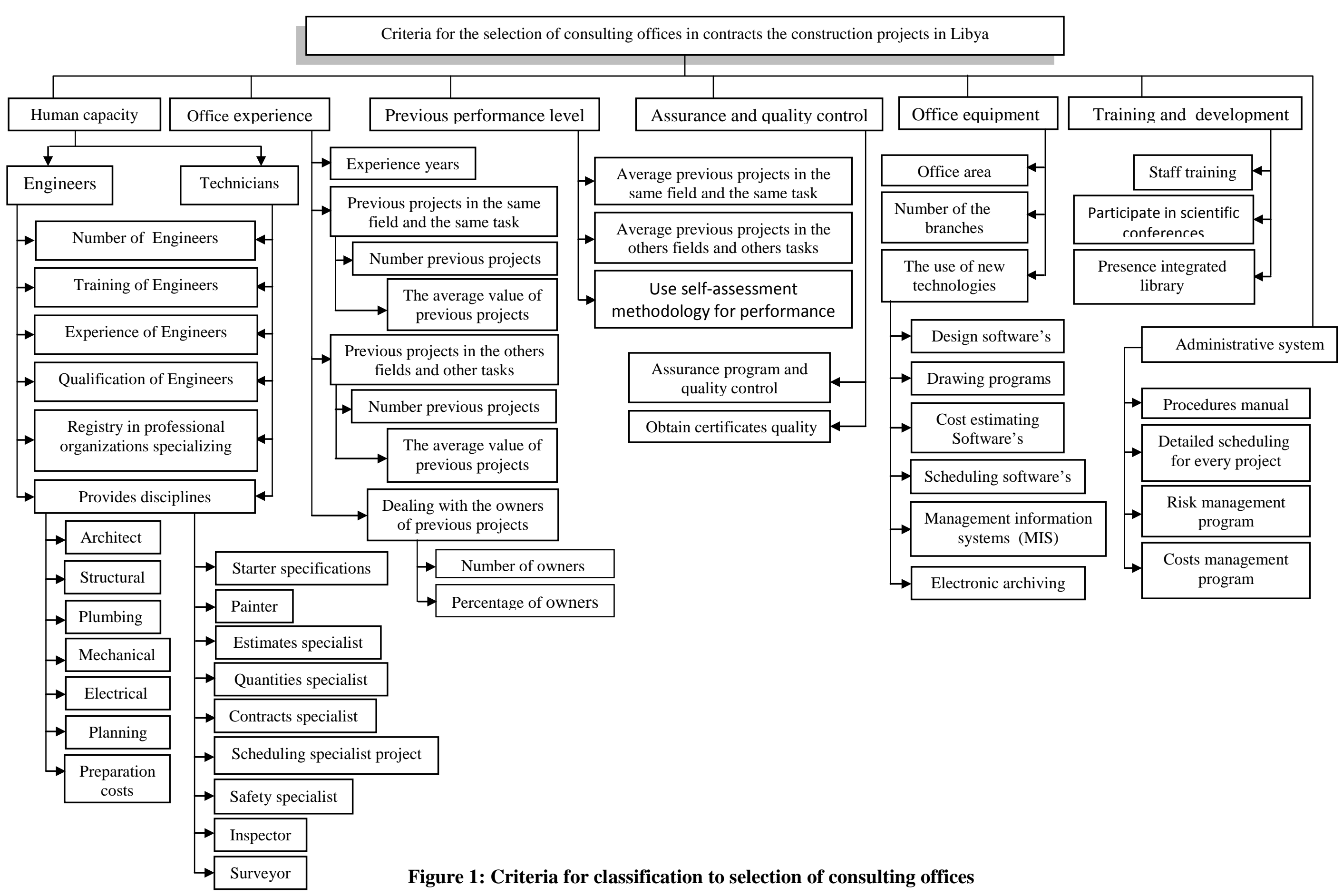




\section{Appendix A: List of chosen experts in Libya Consulting offices/contracting companies}

\begin{tabular}{|c|c|c|}
\hline No. & Expert & Contact information \\
\hline 1. & Alatkan for Engineering Consulting and Contractor & www.upa.org.ly \\
\hline 2. & SARAYA Engineering Consultants & www.sarycons.com \\
\hline 3. & Alasass Consultant Engineers & www.tagecoly.com \\
\hline 4. & AL-WAHA for Engineering and Technical & www.nomadiacompany.com \\
\hline 5. & EHAF Consulting Engineer & www.ehaf.com \\
\hline 6. & ALEMARA OFFICE of Engineering Consultant & www.alemara.ly \\
\hline 7. & ECOU (Engineering and Consulting Office) & $(+218) 214449184$ \\
\hline 8. & Dar Tripoli Engineering Consultants & $(+218) 914269212$ \\
\hline 9. & Al Aman office to Engineering Consultancy & $(+218) 913210678$ \\
\hline 10. & EL AFIFI Expertise House of Engineering Consultant & www.elfifconsultint.com \\
\hline 11. & Consulting Office for Architecture & $(+218) 619091807$ \\
\hline 12. & Office of the Arab city for Consulting Engineers & www.arabcity-ly.com \\
\hline 13. & Office Mimar / Engineering Consultancy & $(+218) 913129846$ \\
\hline 14. & The bridges Office of Engineering Consulting & $(+218) 912101032$ \\
\hline 15. & ECG engineering consulting group & www.ecgsa.com \\
\hline 16. & Sabbour Associates & www.sabbour.com \\
\hline 17. & Experience House Office for Engineering Consultancy & $(+218) 913796921$ \\
\hline 18. & CEGMAN Consulting Engineering Group & www.cegman.com \\
\hline 19. & AL-AMED ENGINEERING Consultants & www.al-amed.com \\
\hline 20. & Africa Bureau Consulting Engineers & $(+218) 925480620$ \\
\hline 21. & Company Al- Aman for Plastic manufacturing. & www.pwct.ly \\
\hline 22. & Majdal Contraction \& Construction & www.railroads.org.ly \\
\hline 23. & National Union Consultants & www.nuc.ly \\
\hline 24. & Immar Tripoli Libya Construction & www.aucc.ly \\
\hline 25. & Arab Union Contracting Co. & www.raba.ly \\
\hline 26. & Motelet construction co. & www.acacos.ly \\
\hline 27. & Nomadia for general construction \& electrical works & www.najmat-eleemar \\
\hline 28. & The national real estate for investment \& construction & www.arabcont.com \\
\hline 29. & Afwag Pre-Engineered Building Co. & www.afwag.com \\
\hline 30. & SAMA General Construction Company & www.sama-ly.com \\
\hline 31. & Arasam Contracting and Real Estate Investment & www.arasam.com.ly \\
\hline 32. & AL-EBHAR general construction \& real estate & www.alebhar.com \\
\hline 33. & Aracekhoon General Contracting co. & www.aracekhoon.com \\
\hline 34. & New Tripoli's Contracting and Real Estate Investment & www.expoarabia.com \\
\hline 35. & (F.E.S.C) FESSATO for Engineering Services & www.fessato.org.ly \\
\hline
\end{tabular}


Appendix B: Questionnaire

(1) Identify the importance of each criterion in the selection of consulting offices
unimportan
(4) important
(2) less important
(5) very important
(3) importance medium

\begin{tabular}{|c|c|c|c|c|c|c|c|}
\hline No. & The main criteria & The sub-criteria & (1) & $(2)$ & (3) & (4) & (5) \\
\hline \multirow{3}{*}{1.} & \multirow{3}{*}{ Firm's background } & 1-Reputation & $\square$ & $\square$ & $\square$ & $\square$ & $\square$ \\
\hline & & 2-Technical competence /qualification & $\square$ & $\square$ & $\square$ & $\square$ & $\square$ \\
\hline & & 3-Experience with similar project & $\square$ & $\square$ & $\square$ & $\square$ & $\square$ \\
\hline \multirow{3}{*}{2.} & \multirow{3}{*}{$\begin{array}{l}\text { Capacity to } \\
\text { accomplish the work }\end{array}$} & 4-Present workload & $\square$ & $\square$ & $\square$ & $\square$ & $\square$ \\
\hline & & 5-Availability to qualified personnel & $\square$ & $\square$ & $\square$ & $\square$ & $\square$ \\
\hline & & 6-Professional qualification/experience & $\square$ & $\square$ & $\square$ & $\square$ & $\square$ \\
\hline \multirow{3}{*}{3.} & \multirow{3}{*}{ Project approach } & 7-Approaches to time schedule & $\square$ & $\square$ & $\square$ & $\square$ & $\square$ \\
\hline & & 8-Approaches to quality & $\square$ & $\square$ & $\square$ & $\square$ & $\square$ \\
\hline & & 9-Design approach / methodology & $\square$ & $\square$ & $\square$ & $\square$ & $\square$ \\
\hline \multirow{2}{*}{4.} & \multirow{2}{*}{ Financial capability } & 10-Financial statement & $\square$ & $\square$ & $\square$ & $\square$ & $\square$ \\
\hline & & 11-Financial references & $\square$ & $\square$ & $\square$ & $\square$ & $\square$ \\
\hline \multirow{3}{*}{5.} & \multirow{3}{*}{ Cost } & 12-Tender price & $\square$ & $\square$ & $\square$ & $\square$ & $\square$ \\
\hline & & 13-Transportation cost & $\square$ & $\square$ & $\square$ & $\square$ & $\square$ \\
\hline & & 14-Consultancy cost & $\square$ & $\square$ & $\square$ & $\square$ & $\square$ \\
\hline \multirow{4}{*}{6.} & \multirow{4}{*}{$\begin{array}{l}\text { Technical ability and } \\
\text { skills }\end{array}$} & 15-CV`s to be provided. & $\square$ & $\square$ & $\square$ & $\square$ & $\square$ \\
\hline & & 16-Personnel & $\square$ & $\square$ & $\square$ & $\square$ & $\square$ \\
\hline & & 17-Plant and equipment. & $\square$ & $\square$ & $\square$ & $\square$ & $\square$ \\
\hline & & 18-Technical expertise of project team. & $\square$ & $\square$ & $\square$ & $\square$ & $\square$ \\
\hline \multirow{2}{*}{7.} & \multirow{2}{*}{$\begin{array}{l}\text { Assurance and } \\
\text { quality control }\end{array}$} & 19- Assurance program and quality control & $\square$ & $\square$ & $\square$ & $\square$ & $\square$ \\
\hline & & 20- Obtain certificates quality & $\square$ & $\square$ & $\square$ & $\square$ & $\square$ \\
\hline \multirow{12}{*}{8.} & \multirow{12}{*}{ Human capabilities } & 21- Number of (Engineers) & $\square$ & $\square$ & $\square$ & $\square$ & $\square$ \\
\hline & & 22- Experience of (Engineers) & $\square$ & $\square$ & $\square$ & $\square$ & $\square$ \\
\hline & & 23- Training of (Engineers) & $\square$ & $\square$ & $\square$ & $\square$ & $\square$ \\
\hline & & 24- Qualification of (Engineers) & $\square$ & $\square$ & $\square$ & $\square$ & $\square$ \\
\hline & & 25- Registry in professional organizations & $\square$ & $\square$ & $\square$ & $\square$ & $\square$ \\
\hline & & 26- Provides disciplines (Engineers) & $\square$ & $\square$ & $\square$ & $\square$ & $\square$ \\
\hline & & 27- Number of. (Technicians ) & $\square$ & $\square$ & $\square$ & $\square$ & $\square$ \\
\hline & & 28- Experience of (Technicians) & $\square$ & $\square$ & $\square$ & $\square$ & $\square$ \\
\hline & & 29- Training of (Technicians) & $\square$ & $\square$ & $\square$ & $\square$ & $\square$ \\
\hline & & 30- Qualification of (Technicians) & $\square$ & $\square$ & $\square$ & $\square$ & $\square$ \\
\hline & & 31- Registry in professional organizations & $\square$ & $\square$ & $\square$ & $\square$ & $\square$ \\
\hline & & 32- Provides disciplines (Technicians) & $\square$ & $\square$ & $\square$ & $\square$ & $\square$ \\
\hline \multirow{5}{*}{9.} & \multirow{5}{*}{ Financial soundness } & 33-Financial stability & $\square$ & $\square$ & $\square$ & $\square$ & $\square$ \\
\hline & & 34-Credit rating & $\square$ & $\square$ & $\square$ & $\square$ & $\square$ \\
\hline & & 35-Banking arrangements and bonding & $\square$ & $\square$ & $\square$ & $\square$ & $\square$ \\
\hline & & 36-Financial status & $\square$ & $\square$ & $\square$ & $\square$ & $\square$ \\
\hline & & 37-Liquidity ratio & $\square$ & $\square$ & $\square$ & $\square$ & $\square$ \\
\hline \multirow{2}{*}{10.} & & 38-Awareness of responsibility & $\square$ & $\square$ & $\square$ & $\square$ & $\square$ \\
\hline & ability & 39-Ability to persuade & $\square$ & $\square$ & $\square$ & $\square$ & $\square$ \\
\hline & & 40-Safety & $\square$ & $\square$ & $\square$ & $\square$ & $\square$ \\
\hline & & 41-Experience modification rating (EMR) & $\square$ & $\square$ & $\square$ & $\square$ & $\square$ \\
\hline 11. & Health and safety & 42-Health and safety on previous projects & $\square$ & $\square$ & $\square$ & $\square$ & $\square$ \\
\hline & & 43-Details of (OSHA) & $\square$ & $\square$ & $\square$ & $\square$ & $\square$ \\
\hline & & 44-Management safety accountability & $\square$ & $\square$ & $\square$ & $\square$ & $\square$ \\
\hline & & 45-Relevance to the project tendered & $\square$ & $\square$ & $\square$ & $\square$ & $\square$ \\
\hline & & 46-Role of the tendered & $\square$ & $\square$ & $\square$ & $\square$ & $\square$ \\
\hline 12. & Relevant experience & 47-Project cost & $\square$ & $\square$ & $\square$ & $\square$ & $\square$ \\
\hline & & 48-Duration of the project & $\square$ & $\square$ & $\square$ & $\square$ & $\square$ \\
\hline & & 49-Staff training & $\square$ & $\square$ & $\square$ & $\square$ & $\square$ \\
\hline 13. & development & 50-Participate in scientific conferences & $\square$ & $\square$ & $\square$ & $\square$ & $\square$ \\
\hline & & 51-Presence integrated library & $\square$ & $\square$ & $\square$ & $\square$ & $\square$ \\
\hline
\end{tabular}




\begin{tabular}{|c|c|c|c|c|c|c|c|}
\hline No. & The main criteria & $\begin{aligned} \text { The sub-criteria } \\
\end{aligned}$ & (1) & (2) & (3) & (4) & (5) \\
\hline \multirow{6}{*}{14.} & \multirow{6}{*}{ Methodology } & 52-program of works & $\square$ & $\square$ & $\square$ & $\square$ & $\square$ \\
\hline & & 53-Key performance indicators & $\square$ & $\square$ & $\square$ & $\square$ & $\square$ \\
\hline & & 54-Division of work into subcontracts & $\square$ & $\square$ & $\square$ & $\square$ & $\square$ \\
\hline & & 55-Innovate procedure to be used & $\square$ & $\square$ & $\square$ & $\square$ & $\square$ \\
\hline & & 56-Reporting and recording systems & $\square$ & $\square$ & $\square$ & $\square$ & $\square$ \\
\hline & & 57-Quality plan & $\square$ & $\square$ & $\square$ & $\square$ & $\square$ \\
\hline \multirow{4}{*}{15.} & \multirow{4}{*}{$\begin{array}{l}\text { Administrative } \\
\text { system }\end{array}$} & 58-Procedures manual & $\square$ & $\square$ & $\square$ & $\square$ & $\square$ \\
\hline & & 59-Detailed scheduling for every project & $\square$ & $\square$ & $\square$ & $\square$ & $\square$ \\
\hline & & 60-Risk management program & $\square$ & $\square$ & $\square$ & $\square$ & $\square$ \\
\hline & & 61-Costs management program & $\square$ & $\square$ & $\square$ & $\square$ & $\square$ \\
\hline \multirow{4}{*}{16.} & \multirow{4}{*}{$\begin{array}{l}\text { Management skills } \\
\text { and systems }\end{array}$} & 62-Quality system & $\square$ & $\square$ & $\square$ & $\square$ & $\square$ \\
\hline & & 63-Project management tools & $\square$ & $\square$ & $\square$ & $\square$ & $\square$ \\
\hline & & 64-Program software & $\square$ & $\square$ & $\square$ & $\square$ & $\square$ \\
\hline & & 65-Environmental management system & $\square$ & $\square$ & $\square$ & $\square$ & $\square$ \\
\hline \multirow{4}{*}{17.} & \multirow{4}{*}{ Reputation } & 66-Past failures & $\square$ & $\square$ & $\square$ & $\square$ & $\square$ \\
\hline & & 67-Length of time in business & $\square$ & $\square$ & $\square$ & $\square$ & $\square$ \\
\hline & & 68-Past owner/contractor relationship & $\square$ & $\square$ & $\square$ & $\square$ & $\square$ \\
\hline & & 69-Other relationships & $\square$ & $\square$ & $\square$ & $\square$ & $\square$ \\
\hline \multirow{4}{*}{18.} & \multirow{4}{*}{ Office equipment } & 70-Office area & $\square$ & $\square$ & $\square$ & $\square$ & $\square$ \\
\hline & & 71-Number consultant office the branches & $\square$ & $\square$ & $\square$ & $\square$ & $\square$ \\
\hline & & 72-The use of new technologies & $\square$ & $\square$ & $\square$ & $\square$ & $\square$ \\
\hline & & 73-Condition of equipment & $\square$ & $\square$ & $\square$ & $\square$ & $\square$ \\
\hline \multirow{10}{*}{19.} & \multirow{10}{*}{$\begin{array}{c}\text { Previous } \\
\text { performance level }\end{array}$} & 74-Quality standards, performance levels & $\square$ & $\square$ & $\square$ & $\square$ & $\square$ \\
\hline & & 75-Time control & $\square$ & $\square$ & $\square$ & $\square$ & $\square$ \\
\hline & & 76-Completion date and extensions & $\square$ & $\square$ & $\square$ & $\square$ & $\square$ \\
\hline & & 77-Failure to completed contract & $\square$ & $\square$ & $\square$ & $\square$ & $\square$ \\
\hline & & 78-Delay & $\square$ & $\square$ & $\square$ & $\square$ & $\square$ \\
\hline & & 79-Cost overruns & $\square$ & $\square$ & $\square$ & $\square$ & $\square$ \\
\hline & & 80-Relationship with insurance companies & $\square$ & $\square$ & $\square$ & $\square$ & $\square$ \\
\hline & & $\begin{array}{l}\text { 81-Assess performance for the previous projects in the } \\
\text { same field and the task }\end{array}$ & $\square$ & $\square$ & $\square$ & $\square$ & $\square$ \\
\hline & & $\begin{array}{l}\text { 82-Assess performance of previous projects in the other } \\
\text { fields and other tasks }\end{array}$ & $\square$ & $\square$ & $\square$ & $\square$ & $\square$ \\
\hline & & $\begin{array}{l}\text { 83-Use of self-assessment methodology after the } \\
\text { completion }\end{array}$ & $\square$ & $\square$ & $\square$ & $\square$ & $\square$ \\
\hline \multirow{8}{*}{20.} & \multirow{8}{*}{ Office experience } & 84-Years of experience & $\square$ & $\square$ & $\square$ & $\square$ & $\square$ \\
\hline & & $\begin{array}{l}\text { 85-Number of previous projects in the same field and } \\
\text { the task }\end{array}$ & $\square$ & $\square$ & $\square$ & $\square$ & $\square$ \\
\hline & & $\begin{array}{l}\text { 86- The average size of previous projects in the same } \\
\text { field and the task }\end{array}$ & $\square$ & $\square$ & $\square$ & $\square$ & $\square$ \\
\hline & & $\begin{array}{l}\text { 87-Number and size of previous projects in the fields } \\
\text { and other tasks }\end{array}$ & $\square$ & $\square$ & $\square$ & $\square$ & $\square$ \\
\hline & & $\begin{array}{l}\text { 88- The average value or size of previous projects in the } \\
\text { fields and other tasks }\end{array}$ & $\square$ & $\square$ & $\square$ & $\square$ & $\square$ \\
\hline & & 89-The number of previous owners & $\square$ & $\square$ & $\square$ & $\square$ & $\square$ \\
\hline & & 90-Percentage of previous owners & $\square$ & $\square$ & $\square$ & $\square$ & $\square$ \\
\hline & & 91-Working with different contract types & $\square$ & $\square$ & $\square$ & $\square$ & $\square$ \\
\hline \multirow{5}{*}{21.} & \multirow{5}{*}{ Price } & 92-Fixed capital cost & $\square$ & $\square$ & $\square$ & $\square$ & $\square$ \\
\hline & & 93-Variable tender costs during the contract period & $\square$ & $\square$ & $\square$ & $\square$ & $\square$ \\
\hline & & 94- Adjustments during the contract period & $\square$ & $\square$ & $\square$ & $\square$ & $\square$ \\
\hline & & 95-Maintenance costs & $\square$ & $\square$ & $\square$ & $\square$ & $\square$ \\
\hline & & 96-Operating costs & $\square$ & $\square$ & $\square$ & $\square$ & $\square$ \\
\hline \multirow{3}{*}{22.} & \multirow{3}{*}{$\begin{array}{l}\text { Management } \\
\text { capability }\end{array}$} & 97-Project management organization & $\square$ & $\square$ & $\square$ & $\square$ & $\square$ \\
\hline & & 98-Experience of technical personnel & $\square$ & $\square$ & $\square$ & $\square$ & $\square$ \\
\hline & & 99-Management knowledge & $\square$ & $\square$ & $\square$ & $\square$ & $\square$ \\
\hline
\end{tabular}


